Printed ISSN : $2406-7415$

Electronic ISSN : 2655 - 9919

DOI: http://dx.doi.org/10.35137/jabk.v8i2.551

Jurnal Akuntansi dan Bisnis Krisnadwipayana

Volume 8 No. 2 (Mei - Agustus) 2021

\title{
PENGARUH PENGETAHUAN PERPAJAKAN, PELAYANAN PERPAJAKAN DAN SANKSI PAJAK TERHADAP KEPATUHAN WAJIB PAJAK BENDAHARA DILINGKUNGAN BADAN NARKOTIKA NASIONAL
}

\author{
Sigit Herdianto \\ Fakultas Ekonomi Universitas Krisnadwipayana \\ Jalan Unkris Jatiwaringin Jakarta Timur
}

ABSTRACT

This study aims to determine and analyze the effect of tax knowledge, tax services and tax sanctions on treasury taxpayer compliance in the National Narcotics Board. The research design used in this study is a descriptive method with a qualitative method approach. Hypothesis Results Partial Test (t) Testing the first hypothesis (H1) states that taxation knowledge does not have a significant effect on taxpayer compliance. Based on statistical parameters, the tcount value is $0.731<2.056$ ( $t$-table). At a significance of $5 \%$ (0.05), it is said that knowledge of taxation has no effect on taxpayer compliance. The second hypothesis testing (H2) states that taxation services do not have a significant effect on taxpayer compliance. Based on statistical parameters, the value of tcount is $-0.292<2.056$ ( $t$ table). At a significance of 5\% (0.05), it is said that taxation services have a negative and insignificant effect on tax compliance of taxpayers. Testing the third hypothesis (H3) states that tax sanctions have no significant effect on taxpayer compliance. Based on statistical parameters, the value of tcount is $-1,955<2,056$ (ttabel). At a significance of 5\% (0.05), it is said that the size of tax sanctions has a negative and insignificant effect on tax compliance of taxpayers. Hypothesis Test Results on the Coefficient of Determination (R2), the R2 value of this study is 0.198, this value means that the total dependent variable is related to an average of 19.8\%. It can be explained by the relationship between tax knowledge, tax services, and tax penalties. Together. While the remaining $80.2 \%$ is influenced by other factors that are not explained in this study.

Keywords: Tax Knowledge, Tax Services and Tax Sanctions

\section{PENDAHULUAN}

Pajak merupakan sumber utama penerimaanNegara.PembangunanNegara dapat terlaksana karena didanai oleh pajak.Pajak merupakan konstribusi kewajiban kepada negara yang terutang oleh orang pribadi atau suatu badan yang sifatnya memaksakan berdasarkan undang-undang, dengan tidak mendapatkan imbalan secara langsung dan digunakan untuk keperluan negara bagi sebesar-besarnya kemakmuran rakyat (Undang-Undang Nomor 28 Tahun 2007).

Self Assessment System ini menuntut seorang wajib pajak agar patuh dalammembayarkan dan melaporkan pajaknya yang terutang sesuai dengan

Copyright (c) 2021 Sigit Herdianto ketentuan perpajakan. Kepatuhan yang diharapkan adalah kepatuhan yang suka rela bukan kepatuhan yang dipaksakan. Dalam upaya meningkatkan kepatuhan yang terbentuk secara sukarela dari seorang Wajib Pajak diperlukan suatu tatanan yg adil dan terbuka dalam menerapkan peraturan perpajakan dan pelayanan yang baik dan cepat terhadap seorang Wajib Pajak.

Tabel 1. Penerimaan Pajak Tahun 2019

\begin{tabular}{|l|l|l|l|}
\hline Uraian & APBN & $\begin{array}{l}\text { Realisasi } \\
\text { Sementara }\end{array}$ & $\begin{array}{l}\% \text { Pendapatan } \\
\text { APBN }\end{array}$ \\
\hline $\begin{array}{l}\text { A. Pendapatan } \\
\text { Negara }\end{array}$ & $2.165,1$ & $1.957,2$ & 90,4 \\
\hline $\begin{array}{l}\text { I. Pendapatan } \\
\text { Dalam Negeri }\end{array}$ & $2.164,7$ & $1.950,4$ & 90,1 \\
\hline
\end{tabular}

246

\section{(c) (i) (5)}

This work is licensed under a Creative Commons Attribution-NonCommercial-ShareAlike 4.0 International License 


\begin{tabular}{|l|l|l|l|}
\hline $\begin{array}{l}\text { 1. Penerimaan } \\
\text { Perpajakan }\end{array}$ & $1.786,4$ & $1.545,3$ & 86,5 \\
\hline $\begin{array}{l}\text { 2. Penerimaan } \\
\text { Negara Bukan } \\
\text { Pajak }\end{array}$ & 378,3 & 405,0 & 107,1 \\
\hline $\begin{array}{l}\text { II. Penerimaan } \\
\text { Hibah }\end{array}$ & 0,4 & 6,8 & $1.560,7$ \\
\hline
\end{tabular}

Sumber: Laporan APBN Tahun 2019 KEMENKEU

Berdasarkan tabel di atas, dapat diketahui bahwa penerimaan darisektor pajak cenderung menurun atau melemah dari pendapatan penerimaan negara lainnya pada tahun 2019. Penerimaanpajakiniditentukanolehkepatuha nmasyarakatdalammemenuhikewajiban perpajakannya sebagaimana yang dikemukakan oleh Sari danAfriyanti (2012) bahwa kepatuhan Wajib Pajak merupakan syarat agarpenerimaan pajak negara meningkat.Menurut (Rustiyaningsih, 2011) Pemerintah masih terus berupaya untukmeningkatkan kepatuhan wajib pajak dalam memenuhi kewajiban perpajakan baikdari penyampaian SPT, ketepatan pembayaran pajak, dan perhitungan/pelaporanyang seharusnya, agar penerimaan negara dari sektor pajak meningkat.

Rendahnyatingkatkepatuhanmemberikanbe berapadampaknegatifsepertipenerimaanneg ara menurun karena hilangnya potensi pendapatan negara, sistem perpajakankurang prospektif dan sistem perpajakan kurang dapat diandalkan sebagai sumberpendapatan. Seperti yang diketahui bahwa penerimaan pajak mengambil proporsi yang sangatdominandi dalam APBN.

Pemerintah juga tidak akan diam dalam menanggapi kasus kepatuhan pajak, beberapa cara dilakukan pemerintah baik dengan ekstensifikasi maupun intensifikasi. Rendahnya kepatuhan seorang wajib pajak tersebut dapat dipengaruhi oleh beberapa faktor, diantaranya yaitu pengetahuan perpajakan, Pelayanan perpajakan dan sanksi perpajakan. Kamil (2015) menyatakan bahwa pengetahuan tentang pajak merupakan penalaran dan pengertian dari pemahaman tentang peraturan perundang-undangan perpajakan, karena dalam memenuhi kewajiban perpajakannya, masyarakat wajib memiliki pengetahuan dan pemahaman tentang peraturan perpajakan tersebutu, tanpa ada pengetahua $\mathrm{n}$ dan pemahaman tentang perpajakan maka kemungkinan mereka tidak akan mau membayar pajak lebih besar.

Faktor lain yang menyebabkan kurangnya kepatuhan Wajib Pajakadalahkurangnyapengetahuanperpajak anyangdimilikiolehWajibPajak.Salahsatucar ayangdapatdilakukanolehaparatpajakdalam mengatasi hal ini adalah dengan cara memberikan sosialisasi peraturanpajakagardapatmeningkatkanpeng etahuanWajibPajakmengenaikewajibannya, masih banyak wajib pajak yang kurang mengerti

betapapentingnyapajakbaginegaradanberaki batpadakurangnyakontribusimasyarakat dalam kepatuhan wajib pajak.Meningkatnya pengetahuan perpajakan yang dimiliki akanberdampak positif pada pemahaman dan kesadaran Wajib Pajak dalammembayarpajaksebagaibentukperanse rtaWajibPajakdalampembiayaanNegaradanj ugapembangunannasional.

Dimana dikatakan oleh (Khasanah \&Novi, 2013) bahwa pengetahuan pajak merupakan pengetahuan mengenai konsepketentuan umum dibidang 
perpajakan, jenis pajak yang berlaku di Indonesia mulaidari subyek pajak, obyek pajak, tarif pajak, perhitungan pajak terutang,

pencatatanpajakterutangsampaidenganbagai manapengisianpelaporanpajak.Dapatdisimp ulkanbahwapengetahuanpajakadalahinform asipajakyangdapatdigunakan oleh wajib pajak sebagai dasar untuk bertindak, mengambil keputusandan untuk menempuh arah atau strategi tertentu sehubungan dengan pelaksanaanhakdan kewajibannyadibidangperpajakan.

Tingginya tingkat pengetahuan perpajakan wajib pajak mengenai tata caramemenuhi kewajiban perpajakan, fungsi, dan peranan pajak dapat meningkatkankepatuhan wajib pajak. Hal ini sesuai dengan teori yang dinyatakan oleh (Gintinget al., 2017) bahwa semakin tinggi tingkat pendidikan atau pengetahuan

wajibpajak,makasemakinmudahpulabagiwaj ibpajakmemenuhikewajibanperpajakannya.

Pelayanan juga memiliki pengaruh dalam pembentukan kepatuhan wajib pajak bendaharawan pemerintah. Pelayanan yang berkualitas terhadap wajib pajak adalah usaha yang dilakukan oleh kantor pelayanan pajak untuk melayani wajib pajak secara maksimal agar wajib pajak tidak mengalami kebingungan saat membayar pajak yaitu dengan banyaknya sosialisasi tentang perpajakan dan pelaporannya. Pelayanan yang diberikan oleh aparat pada kantor pajak berkaitan dengan sikap wajib pajak. Dalam proses perpajakan aparat pajak sangat berkontribusi kepada wajib pajak untuk membuat pelayanan yang diberikan oleh aparat pajak dalam upaya pembentukan sikap (atitude) wajib pajak akan memiliki sikap yang baik dak aktif terhadap proses perpajakan. Namun jika pelayanan yang diberikan tidak baik, hal itu akan membuat wajib pajak enggan membayar pajak sesuai ketentuan yang berlaku.Sedangkan pada kualitas pelayanan di sebuah kantor pajak dianggap pelayanan menjadi salah satu indikator penilaian Wajib Pajak dalam kesediannya wajib pajak untuk membayar pajak khususnya dalam penerapan self assessment system yang bertujuan untuk meningkatkan kepatuhan membayar pajak (Susmita \& Supadmi 2016).

Selain itu kepatuhan wajib pajak bendaharawan pemerintah juga dapat ditingkatkan dengan menerapkan sanksi yang tegas. Sanksi pajak yang tegas akan mempengaruhi wajib pajak dalam membayar pajak karena wajib pajak merasa memiliki beban yang harus dibayar atas penghasilan yang tidak dilaporkan apabila nantinya ditemukan oleh administrasi pajak akan lebih besar daripada keuntungan yang mereka peroleh dari penghematan pajak yang dinikmati sekarang karena adanya penghasilan yang tidak dilaporkan. Dengan sanksi yang tegas dari aparat pajak terhadap wajib pajak akan meningkatkan kepatuhan seorang wajib pajak dalam melaksanakan tanggungjawabnya yaitu membayar pajak terutangnya sesuai dengan ketentuan Undang-Undang Perpajakan (UU No.36 Tahun 2008). Sanksi pajak merupakan jaminan bahwa ketentuan peraturan perundang-undangan perpajakan (norma perpajakan) akan dituruti/ditaati/dipatuhi, dengan kata lain sanksi perpajakan merupakan alat pencegah agar wajib pajak tidak melanggar norma perpajakan atau patuh dalam perpajakan (Muliari Setiawan,2011:4). 
Printed ISSN : $2406-7415$

Electronic ISSN : 2655 - 9919

DOI: $\underline{\text { http://dx.doi.org/10.35137/jabk.v8i2.551 }}$

Perbedaan dengan penelitian sebelumnya yaitu apabila penelitian sebelumnya menggunakan wajib pajak orang pribadi sebagai alat ukur, maka penulis mengukur dari wajib pajak bendahara instansi pemerintah yaitu bendahara di lingkungan Badan Narkotika Nasional. Dilakukannya uji kepatuhan perpajakan ini dinilai dari dengan indikator pengetahuan perpajakan, pelayanan perpajakan dan saksi pajak sebagai tolak ukur kepatuhan perpajakan wajib pajak seorang bendahara dilingkungan Badan Narkotika Nasional. Peneliti ingin menguji bagaimana pengaruh pengetahuan perpajakan, pelayanan perpajakan dan sanksi pajak terhadap tingkat kepatuhan wajib pajak bendahara di lingkungan BNN, dan apakah tingkat kepatuhan perpajakan wajib pajak bendahara di lingkungan BNN sudah sesuai dengan aturan yang berlaku pada saat ini dalam menjalankan kewajibannya. Dengan tingkat kepatuhan wajib pajak bendahara yang dilaksanakan kemungkinan dapat membantu pemerintah dalam meningkatkan proporsi penerimaan perpajakan negara. Oleh karena itu penulis tertarik untuk mengkaji secara ilmiah mengenai kepatuhan wajib pajak. Berdasarkan uraian tersebut di atas maka yang menjadi permasalahan dalam penelitian iniadalah sebagai berikut

1. Bagaimana pengaruh pengetahuan perpajakan terhadap kepatuhan wajib pajak bendaharawan pemerintah ?

2. Bagaimana pengaruh pelayanan perpajakan terhadap kepatuhan wajib pajak dalam memenuhi kewajiban bendaharawan pemerintah?

3. Bagaimana pengaruh sanksi pajak terhadap kepatuhan wajib pajak
Jurnal Akuntansi dan Bisnis Krisnadwipayana Volume 8 No. 2 (Mei - Agustus) 2021

dalam memenuhi kewajiban bendaharawan pemerintah ?

4. Bagaimana pengaruh pengetahuan perpajakan, pelayanan perpajakan dan sanksi pajak terhadap kepatuhan wajib pajak dalam memenihi kewajibann bendaharawan pemerintah?

\section{LANDASAN TEORI}

\section{Pajak}

Pajak adalah suatu kontribusi wajib kepada negara yang terutang oleh orang pribadi atau badan yang sifatnya memaksakan berdasarkan Undang-Undang, dengan tidak mendapatkan imbalan secara langsung dan pajak tersebut digunakan untuk keperluan negara bagi sebesarbesarnya kemakmuran rakyat, pengertian pajak menurut Undang-Undang Nomor 28 Tahun 2007 tentang "Perubahan Ketiga Atas Undang-Undang Nomor 6 Tahun 1983 Tentang Ketentuan Umum Perpajakan". Menurut Prof. Rochmat Soemitro berdasarkan Undang-Undang Republik Indonesia Nomor 16 Tahun 2009 tentang perubahan keempat atas Undang-Undang Nomor 6 Tahun 1983 tentang Ketentuan Umum dan Tata Cara Perpajakan Pasal 1 Ayat (I), Pajak adalah kontribusi wajib kepada Negara yang terutang oleh orang pribadi atau badan yang sifatnya memaksakan berdasarkan Undang-Undang, dengan tidak mendapatkan imbalan secara langsung dan digunakan untuk keperluan Negara dan sebesar-besarnya bagi kemakmuran rakyat (Mardiasmo, 2016:3). 


\section{Pengetahuan Perpajakan}

Pengetahuanteknisperpajakandidefinis ikan oleh Hartoyo (2010) yaitu suatu hasil tahu seseorang dari prosespenginderaanterhadapsuatuobjekterte ntuyangberkaitandenganteknisperpajakan.

Pengetahuanteknisperpajakandipengar uhiolehbeberapadiantaranyaadalah(Notoatm odjo,2003 dalam Hartoyo, 2010):

1. PendidikanPerpajakan

2. PersepsidalamMasalahPerpajakan

3. MotivasiatauKeinginan untukMempelajariPajak

4. PengalamandalamPerpajakan

Subandi dan Fadhil (2018) menyatakan bahwa kepatuhan pajak merupakan kesadaran seorang Wajib Pajak dalam melaksanakan kewajiban perpajakannya sesuai peraturan perundangundangan perpajakan yang berlaku secara baik dan benar.

\section{Pelayanan Perpajakan}

Menurut Fuadi dan Mangoting (2013), pelayanan pajak merupakan suatu faktor eksternal yang dapat mempengaruhi tingkat kepatuhan wajib pajak dalam melaksanakan kewajiban perpajakannya. Direktorat Jenderal Pajak dalam hal ini selaku pihak pemerintahan harus menjalankan fungsi pelayanan dengan baik untuk meningkatkan kepatuhan dari wajib pajak itu sendiri agar penerimaan pajak dapat terus meningkat. Dalam memberikan pelayanannya Direktorat Jenderal Pajak tentunya harus memenuhi kepuasan pemangku kepentingan yaitu wajib pajak yang dilakukan dengan sepenuh hati, transparan, akurat, cepat dan aman. Dalam hal meningkatkan pelayanan diperlukan dua perilaku utama untuk mewujudkannya, yaitu: (1) pelayanan dengan berorientasi pada kepuasan pemangku kepentingan yaitu wajib pajak; dan (2) mampu bersikap proaktif dan cepat tanggap dalam melaksanakan tugasnya (Pajak.go.id 2012).

\section{Sanksi Pajak}

Sanksi adalah sebuah hukuman negatif yang dijatuhkan atau diberikan kepada orang yang melanggar peraturan dan denda. Sanksi tersebut berupa hukuman dengan cara membayar uang karena melanggar peraturan dan hukum yang berlaku, sehingga dapat dikatakan bahwa sanksi denda adalah hkuman negatif kepada orang yang melanggar peraturan dengan cara membayar uang menurut Jatmiko (2006). IndikatordarisanksipajakitusendirimenurutY adyana(2009)adalahsebagaiberikut :

1. Sanksipidanayangdikenakanbagipelangga $r$ aturancukupberat.

2. Sanksiadministrasiyangdikenakanbagipel anggaraturanpajaksangatringan.

3. Pengenaansanksiyangcukupberatmerupak ansalahsatusaranamendidikwajib pajak.

4. Sanksipajakharusdikenakankepadapelang garnyatanpatoleransi.

5. Pengenaansanksiataspelanggaranpajakda patdinegosiasikan.

\section{Kepatuhan Perpajakan}

Dalam hal pajak, aturan yang berlaku
adalah aturan perpajakan.
Jadidalamhubungannya dengan wajib pajak yang
patuh, maka pengertian kepatuhan


wajibpajakmerupakansuatuketaatanuntukmelaku kanketentuan-ketentuanatauaturan-

aturanperpajakanyangdiwajibkanataudiharuskan untukdilaksanakan(Kiryanto,2000). Ismawan (2001) dalam Hartoyo (2010) mengemukakan bahwa prinsip pajakyang diterima secara luas memiliki tujuan yang ingin dicapai yaitu kepatuhansukarela. Kepatuhan sukarela merupakan fondasi dari sistem self assessmentdi mana wajib pajak bertanggung jawab menetapkan sendiri kewajiban pajaknyadan kemudian secara akurat dan tepat waktu membayar dan melaporkan pajaktersebut.Ismawanjugamenyebutkanbahwak epatuhansebagaifondasiselfassessment dapat dicapai apabila elemen-elemen kunci telah diterapkan secaraefektif.Elemen-elemen kunci tersebutadalah sebagai berikut:

1. Programpelayananyangbaikkepada wajibpajak.

2. Proseduryangsederhana danmemudahkanwajibpajak.

3. Programpemantauankepatuhandanverivikasi yangefektif.

4. Pemantapanlawenforcement secarategasdanadil.

Jatmiko (2006)menyatakan bahwa kepatuhan wajibpajak diidentifikasikan sebagai memasukkan dan melaporkan kepada waktunyainformasi yang diperlukan, mengisi secara benar jumlah pajak yang terutang, danmembayar pajak pada waktunya tanpa tindakan pemaksaan. Ketidakpatuhan wajibpajaktimbul kalau salahsatusyarat definisi tidak terpenuhi.Ada dua macam kepatuhan, yaitu kepatuhan formal dan kepatuhan material.Kepatuhanformaladalahsuatukeadaandi manawajibpajakmemenuhikewajibansecaraform alsesuaidenganketentuandalamundangundangperpajakan. Sedangkan kepatuhan material adalah suatu keadaan dimana wajibpajakmemenuhisemuaketentuanmaterialper pajakan,yaknisesuaidenganisidanjiwaundangundangperpajakan.Kepatuhanmaterialdapatjuga meliputikepatuhanformal(Winerungan, 2013).

\section{Kerangka Konseptual}

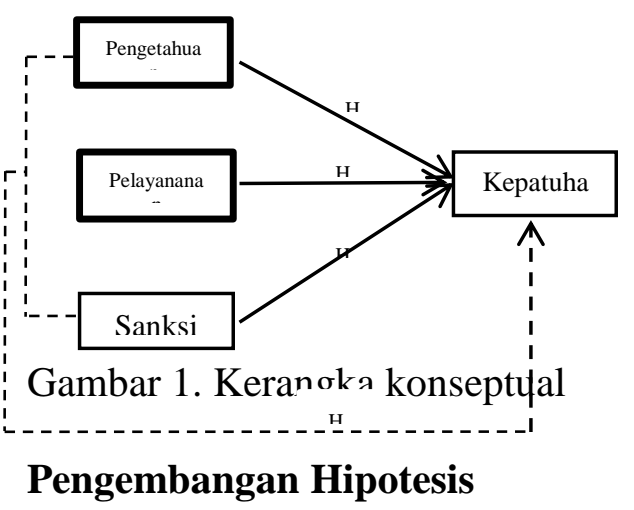

\section{Pemahaman Perpajakan dan Kepatuhan Bendaharawan Pemerintah}

Dalam melaksanakan tugasnya tingkat pemahaman seorang wajib pajak mengenai perpajakan dinilai sangat penting dalam menentukan sikap perpajakan dan perilaku wajib pajak dalam melaksanakan kewajibannya. Pemahaman perpajakan meliputi:

1. Pengisian surat pemberitahuan dengan benar;

2. Perhitungan pajak yang sesuai dengan pajak yang terutang yang ditanggung wajib pajak. Penyetoran pajak secara tepat waktu sesuai dengan waktu yang ditentukan;

3. Pelaporan atas pajaknya ke kantor pajak yang telah terdaftar.

Menurut Muslim (2007: 11) dalam Yunita (2015) Pengetahuan dan pemahaman terhadap perpajakan yang semakin tinggi 
Printed ISSN : $2406-7415$

Electronic ISSN : 2655 - 9919

Jurnal Akuntansi dan Bisnis Krisnadwipayana Volume 8 No. 2 (Mei - Agustus) 2021

bagi seorang wajib pajak, maka semakin kecil kemungkinan wajib pajak untuk melanggar peraturan tersebut sehingga meningkatkan tingkat kepatuhan wajib pajak. Pemahaman dan pengetahuan pajak memiliki dampak yang siginifikan terhadap kepatuhan pajak. Pengetahuan dan pemahaman tentang aturan perpajakan menjadi dasar bagi wajib pajak untuk melaksanakan kewajiban perpajakan. Pemahaman wajib pajak (bendahara) terhadap peraturan perpajakan dapat meningkatkan kepatuhan Wajib Pajak dalam melaksanakan kewajibannya. Berdasarkan hal tersebut maka dirumuskan hipotesis sebagai berikut:

H1 : Diduga bahwa pengetahuan pajak berpengaruh positif terhadap tingkat kepatuhan

\section{Pelayanan perpajakan dan kepatuhan bendaharawan pemerintahan.}

Pelayanan pajak dinilai sebagai faktor eksternal yang dapat mempengaruhi tingkat kepatuhan wajib pajak dalam melaksanakan kewajiban perpajakannya (Fuadi dan Mangoting 2013). Pelayanan aparat perpajakan terhadap kepatuhan wajib pajak terkait erat (Syamsurizal 2017). Penelitian ini menunjukkan pelayanan aparat perpajakan di KPP Pratama Jakarta Kalideres sangat membantu wajib pajak memenuhi kewajiban perpajakannya. Sehingga dengan pelayanan yang baik mendorong wajib pajak untuk semakin taat melakukan pembayaran pajak tepat waktu. Berdasarkan hal tersebut maka dirumuskan hipotesis sebagai berikut:

\section{H2 : Diduga bahwa pelayanan perpajakan berpengaruh positif terhadap tingkat kepatuhan}

\section{Sanksi pajak dan kepatuhan bendaharawan pemerintah}

Sanksi perpajakan dinilai sebagai suatu jaminan bahwa ketentuan peraturan perundang-undangan perpajakan (norma perpajakan) akan ditaati dan dipatuhi oleh seorang wajib pajak. Begitu pula sanksi pajak dapat diartikan sebagai alat pencegah (preventif) agar seorang wajib pajak tidak melanggar peraturan perpajakanyang berlaku (Mardiasmo, 2016:62). Penelitian Subandi dan Fadhil (2018) sejalan dengan penelitian yang dilakukan kamil (2015) Honandar (2016) yang menyatakan bahwa sanksi pajak berpengaruh positif dan signifikan terhadap kepatuhan wajib pajak. Pemberian sanksi terhadap wajib pajak dianggap mampu meningkatkan kepatuhannya dalam melaksanakan kewajiban perpajakan. Semakin tinggi sanksi yang dikenakan semakin rendah arah koreksi penghasilan netto dari penghasilan netto menurut SPT ataupun sebaliknya. Artinya semakin tinggi sanksi yang dikenakan, tingkat kepatuhan wajib pajakpun akan semakin tinggi. Ini sejalan dengan teori ketidakpatuhan, dimana wajib pajak akan cenderung patuh apabila utility kepatuhan lebih besar daripada utility ketidakpatuhan. Berdasarkan uraian diatas dirumuskan hipotesis ketiga sebagai berikut:

H3 : Diduga bahwa sanksi pajak berpengaruh positif terhadap tingkat kepatuhan. 


\section{METODE PENELITIAN}

\section{Lokasi dan Waktu Penelitian}

Penelitian ini dilaksanakan di Lingkungan Satker Badan Narkotika Nasional. Waktu penelitian ini dilaksanakan pada bulan Maret 2020, dilanjutkan analisis data dan penyusunan laporan penelitian pada bulan Juli dan Agustus 2020.

\section{Desain Penelitian}

Pendekatan yang digunakan dalam penelitian ini adalah pendekatan kuantitatif karena data yang disajikan berhubungan dengan angka (kuantitatif) dan analisis yang digunakan adalah statistik. Data kuantitatif berupa daftar pemungutan pajak SSP/Efilling. Jenis penelitian yang digunakan yaitu penelitian deskriptif.

\section{Populasi dan Sampel Penelitian}

Populasi pada penelitian ini adalah 130 Bendahara Pengeluaran di Lingkungan Satker Badan Narkotika Nasional. Sampel dalam penelitian ini adalah 30 Bendahara Pengeluaran di Lingkungan Satker Badan Narkotika Nasional. Metode pengambilan sampel dalam penelitian ini mengunakan PurposiveSampling.Sumber data yang digunakan dalam penelitian ini yaitu data primer dengan menyebarkan kuisioner kepada wajib pajak bendaharayang menjadi sampel penelitian.

\section{Teknik Pengumpulan Data dan Pengukuran variabel}

\footnotetext{
Copyright (c) 2021 Sigit Herdianto
}

Data diperoleh dengan mengirimkan kuisioner langsung kepada responden yaitu semua bendahara pengeluaran pemerintah di Lingkungan Satker Badan Narkotika Nasional. Jumlah sampel dari penelitian ini adalah 30 bendaharawan pengeluaran pemerintah.

Tabel 2. Definisi Operasional Variabel

\begin{tabular}{|c|c|c|}
\hline Variabel & $\begin{array}{l}\text { IndikatorP } \\
\text { ertanyaan }\end{array}$ & $\begin{array}{l}\text { Penguk } \\
\text { uran }\end{array}$ \\
\hline $\begin{array}{l}\text { Kepatuhan Perpajakan } \\
\text { WajibPajak(Kepatuhan } \\
\text { Perpajakan_WP) }\end{array}$ & 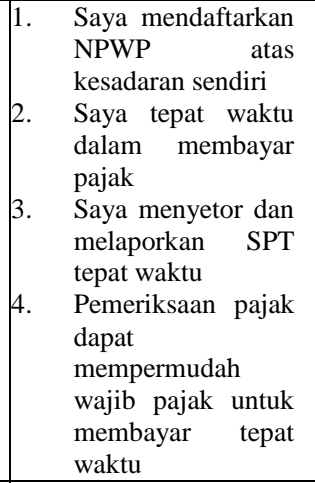 & $\begin{array}{l}\text { SkalaLik } \\
\text { ert }\end{array}$ \\
\hline $\begin{array}{l}\text { PengetahuanPerpajakan }(\mathrm{Pe} \\
\text { ngetahuan) }\end{array}$ & $\begin{array}{llr}\text { 1. } & \text { Pajak selaku } \\
\text { instrument hukum } & \text { yang diatur oleh } \\
& \text { Undang-Undang } \\
\text { adalah suatu } & \text { kewajiban yang } \\
\text { mengikat bagi } & \text { setiap Wajib Pajak } \\
\text { (WP) } \\
\text { Pajak mempunyai } \\
\text { sifat memaksa } \\
\text { 3. Pajak merupakan } \\
\text { penerimaan Negara } \\
\text { yang digunakan } \\
\text { untuk mengarahkan } \\
\text { kehidupan } \\
\text { masyarakat menuju } \\
\text { kesejahteraan } \\
\text { Saya mengetahui } \\
\text { syarat-syarat untuk } \\
\text { mendaftarkan } \\
\text { NPWP, baik syarat } \\
\text { subyektif maupun } \\
\text { objektif } \\
\text { Saya mengetahui } \\
\text { tata cara } \\
\text { mendaftarkan } \\
\text { NPWP (Nomor } \\
\text { Pokok Wajib } \\
\text { Pajak) } \\
\text { Saya mengetahui } \\
\text { fungsi NPWP }\end{array}$ & $\begin{array}{l}\text { Skala } \\
\text { Likert }\end{array}$ \\
\hline
\end{tabular}


Printed ISSN : $2406-7415$

Electronic ISSN : 2655 - 9919

DOI: http://dx.doi.org/10.35137/jabk.v8i2.551

Jurnal Akuntansi dan Bisnis Krisnadwipayana Volume 8 No. 2 (Mei - Agustus) 2021

\begin{tabular}{|c|c|c|}
\hline & 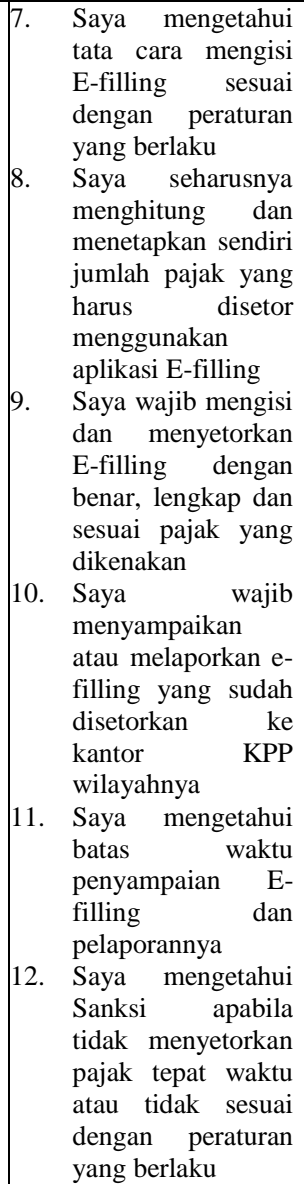 & \\
\hline $\begin{array}{l}\text { Pelayanan Perpajakan } \\
\text { (Pelayanan) }\end{array}$ & 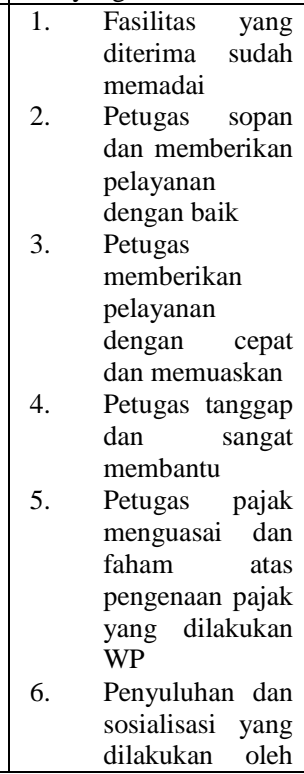 & $\begin{array}{l}\text { Skala } \\
\text { Likert }\end{array}$ \\
\hline
\end{tabular}

\begin{tabular}{|c|c|c|c|}
\hline & & $\begin{array}{lr}\text { petugas } & \text { dapat } \\
\text { membantu } & \\
\text { pemahaman } & \\
\text { anda mengenai } \\
\text { hak } & \text { dan } \\
\text { kewajiban } & \text { anda } \\
\text { selaku WP } & \\
\text { Teknologi } & \text { yang } \\
\text { digunakan } & \text { KPP } \\
\text { sudah } & \text { cukup } \\
\text { modern } & \\
\text { Gedung } & \text { KPP } \\
\text { sudah rakup } & \text { cukdern } \\
\text { modersih, } \\
\text { rapih r dan } \\
\text { nyaman) }\end{array}$ & \\
\hline Sanksi Pajak(Sanksi) & 1. & 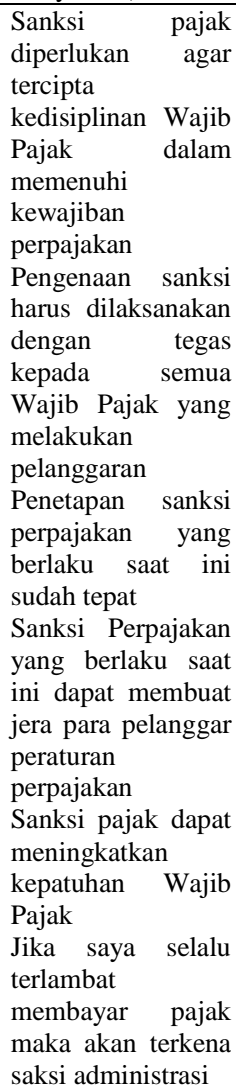 & $\begin{array}{l}\text { Skala } \\
\text { Likert }\end{array}$ \\
\hline
\end{tabular}

Metode Analisis Data

Analisis data yang digunakan dalam penelitian ini adalah analisis regresi linier berganda. Analisis regresi linier berganda adalah hubungan secara linier antara dua 
Printed ISSN : $2406-7415$

Electronic ISSN : 2655 - 9919

DOI: http://dx.doi.org/10.35137/jabk.v8i2.551

Jurnal Akuntansi dan Bisnis Krisnadwipayana Volume 8 No. 2 (Mei - Agustus) 2021

atau lebih variabel independen dengan satu variabel dependen yang digunakan untuk memprediksi atau meramalkan suatu nilai variabel dependen berdasarkan variabel independen. Dengan persamaan yaitu :

$$
Y=\mathbf{a}+\mathrm{b}_{1} X_{1}+\mathrm{b}_{2} X_{2}+\mathrm{b}_{3} X_{3}+\varepsilon
$$

Keterangan:

$\begin{array}{ll}\mathrm{Y} & : \text { Kepatuhan Wajib Pajak } \\ \mathrm{a} & : \text { Konstanta } \\ \mathrm{b}_{1}, \mathrm{~b}_{2} \text { dan } \mathrm{b}_{3} & \\ : & \\ \text { Koefisien Regresi } \\ \mathrm{X}_{1} & \text { : Pengetahuan Perpajakan } \\ \mathrm{X}_{2} & \text { : Pelayanan Perpajakan } \\ \mathrm{X}_{3} & \text { : Sanksi Perpajakan }\end{array}$

PEMBAHASAN DAN HASIL

\section{Deskripsiresponden}

\begin{tabular}{|c|c|c|}
\hline No & Keterangan & Jumlah/Presentase \\
\hline 1 & Kuesioner Disebar & 130 eksemplar \\
\hline 2 & Kuesioner Kembali & 30 eksemplar \\
\hline 3 & $\begin{array}{l}\text { Kuesioner yang Dapat } \\
\text { Diolah }\end{array}$ & 30 eksemplar \\
\hline No & Keterangan & Jumlah/Presentase \\
\hline 1 & Kuesioner Disebar & 130 eksemplar \\
\hline 2 & Kuesioner Kembali & 30 eksemplar \\
\hline 3 & $\begin{array}{l}\text { Kuesioner yang Dapat } \\
\text { Diolah }\end{array}$ & 30 eksemplar \\
\hline
\end{tabular}

Tabel 3.Penyebaran Kuesioner

\begin{tabular}{||l|l|c|}
\hline Jenis Kelamin & Jumlah & Presentase \\
\hline Laki-laki & 8 & $26,67 \%$ \\
\hline & & \\
\hline Perempuan & 22 & $33,33 \%$ \\
\hline Total & 30 & $100 \%$ \\
\hline
\end{tabular}

Tabel 4. Klasifikasi Responden Berdasarkan Jenis Kelamin

wajib pajak satuan kerja di lingkungan Badan Narkotika Nasional yang terdaftardiKPPPratamadenganjumlahrespon densebanyak130orang,130 eksamplar kuesioner yang diberikan kepada responden dan sebanyak 30 eksamplar kuisioner telah diisi secara lengkap dan benar sehingga layak untuk dianalisis lebih lanjut untuk kepentingan penelitianini.

\section{DemografiResponden}

Berdasarkan hasil penelitian yang telah dilakukan penulis terhadap 30 responden pada bendahara satker di lingkungan Badan Narkotika Nasional, maka dapat diidentifikasikan mengenai karakteristik responden sebagai berikut:

\section{JenisKelamin}

Berdasarkan jenis kelamin, maka responden dalam penelitian ini dapat diklasifikasikan sebagai berikut:

Berdasarkan Jenis Kelamin

\footnotetext{
Copyright (c) 2021 Sigit Herdianto
} 


\section{Usia}

Berdasarkan usia, maka responden dalam penlitian ini dapat diklasifikasikan sebagai berikut:

\begin{tabular}{|l|l|l|l|}
\hline No & Usia & Jumlah & Persentase \\
\hline 1 & $<25^{\text {th }}$ & 4 & $13,33 \%$ \\
\hline 2 & $25-35$ & 18 & $60,00 \%$ \\
\hline 3 & $36-45$ & 8 & $26,67 \%$ \\
\hline & Total & 30 & $100 \%$ \\
\hline
\end{tabular}

Tabel 5. Klasifikasi Responden Berdasarkan Usia

\section{TingkatPendidikan}

Berdasarkan tingkat pendidikan, maka responden dalampenelitian ini dapat diklasifikasikan sebagai berikut:

\begin{tabular}{|l|l|l|l|}
\hline No & Pendidikan & Jumlah & Persentase \\
\hline 1 & D3 & 13 & $43,33 \%$ \\
\hline 2 & S1 dan S2 & 17 & $56,67 \%$ \\
\hline \multicolumn{2}{|l}{ Total } & 30 & $100 \%$ \\
\hline
\end{tabular}

Tabel 6. Klasifikasi Responden Berdasarkan Tingkat Pendidikan

\section{Metode Analisis Data}

\section{Uji ValiditasData}

Tabel 7. Hasil Uji Validitas Item-item Variabel Penelitian

\begin{tabular}{|l|l|l|l|}
\hline Item & Rxy & $\begin{array}{l}\mathrm{r}- \\
\text { tabel }\end{array}$ & $\begin{array}{l}\text { Keterang } \\
\text { an }\end{array}$ \\
\hline $\begin{array}{l}\text { Pajak selaku instrument } \\
\text { hukum yang diatur oleh }\end{array}$ & 0,36 & Valid \\
$\begin{array}{l}\text { Undang-Undang adalah } \\
\text { nndang }\end{array}$ & 1 & \\
\hline
\end{tabular}

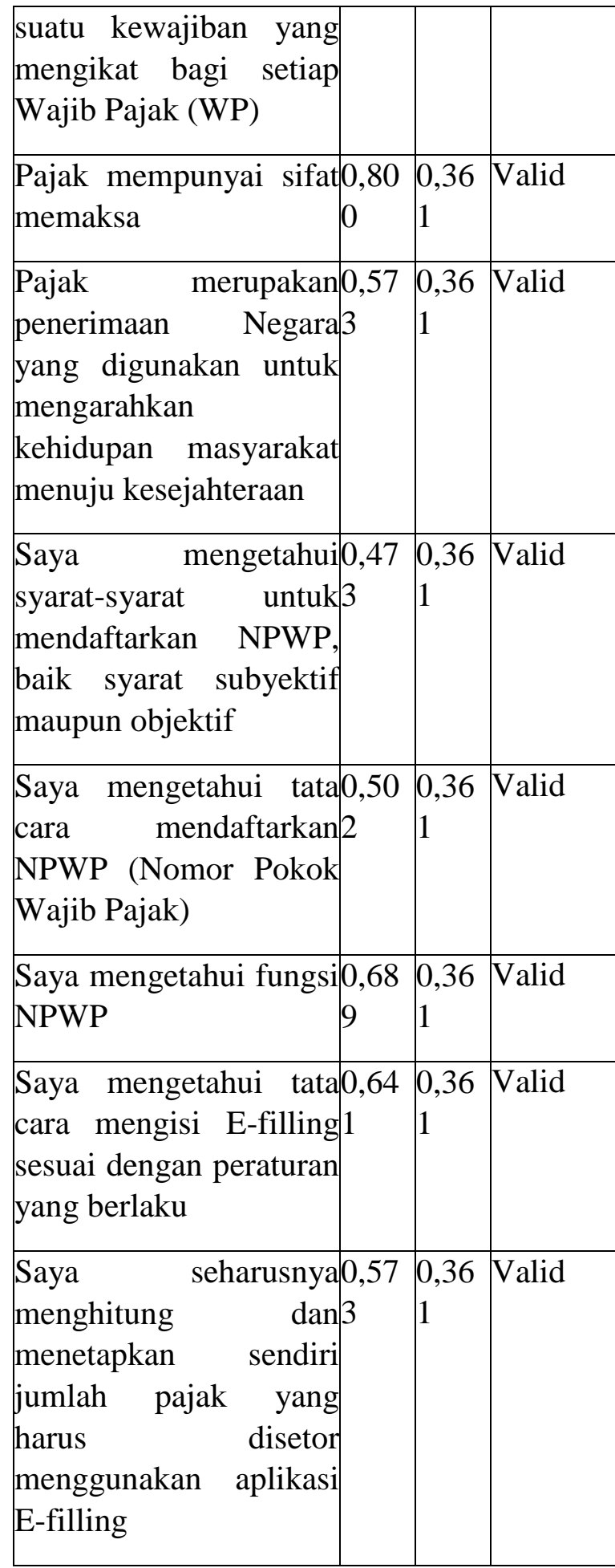




\begin{tabular}{|c|c|c|}
\hline 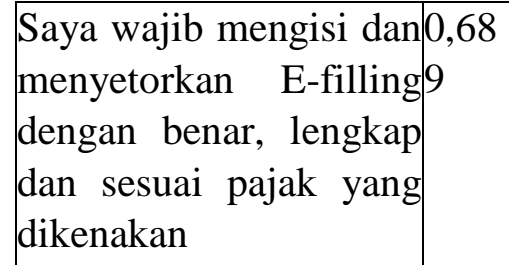 & $\begin{array}{l}0,36 \\
1\end{array}$ & Valid \\
\hline 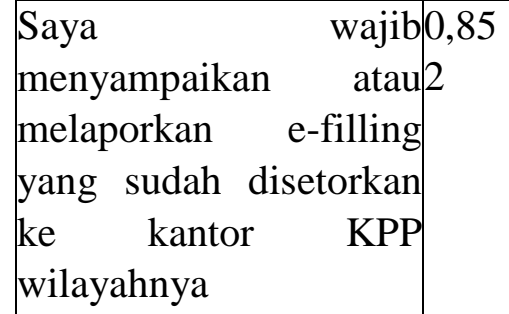 & $\begin{array}{l}0,36 \\
1\end{array}$ & Valid \\
\hline $\begin{array}{l}\text { Saya mengetahui batas } \\
\text { waktu penyampaian } \mathrm{E}-3 \\
\text { filling } \\
\text { pelaporannya }\end{array}$ & $\begin{array}{l}0,36 \\
1\end{array}$ & Valid \\
\hline $\begin{array}{lr}\text { Saya mengetahui } & 0,50 \\
\text { Sanksi apabila tidak } 2 & 2 \\
\text { menyetorkan } & \text { pajak } \\
\text { tepat waktu atau tidak } \\
\text { sesuai dengan peraturan } \\
\text { yang berlaku }\end{array}$ & $\begin{array}{l}0,36 \\
1\end{array}$ & Valid \\
\hline \begin{tabular}{l|l} 
Fasilitas yang diterima & 0,67 \\
sudah memadai
\end{tabular} & $\begin{array}{l}0,36 \\
1\end{array}$ & Valid \\
\hline $\begin{array}{l}\text { Petugas sopan dan } 0,39 \\
\text { memberikan pelayanan } 3 \\
\text { dengan baik }\end{array}$ & $\begin{array}{l}0,36 \\
1\end{array}$ & Valid \\
\hline $\begin{array}{l}\text { Petugas memberikan } 0,67 \\
\text { pelayanan dengan cepat } 7 \\
\text { dan memuaskan }\end{array}$ & $\begin{array}{l}0,36 \\
1\end{array}$ & Valid \\
\hline \begin{tabular}{|lr|l} 
Petugas tanggap dan & 0,39 \\
sangat membantu &
\end{tabular} & $\begin{array}{l}0,36 \\
1\end{array}$ & Valid \\
\hline $\begin{array}{l}\text { Petugas } \\
\text { menguasai dan } \text { faham } 9,68\end{array}$ & $\begin{array}{l}0,36 \\
1\end{array}$ & Valid \\
\hline
\end{tabular}

\begin{tabular}{|c|c|c|}
\hline $\begin{array}{l}\text { atas pengenaan pajak } \\
\text { yang dilakukan WP }\end{array}$ & & \\
\hline 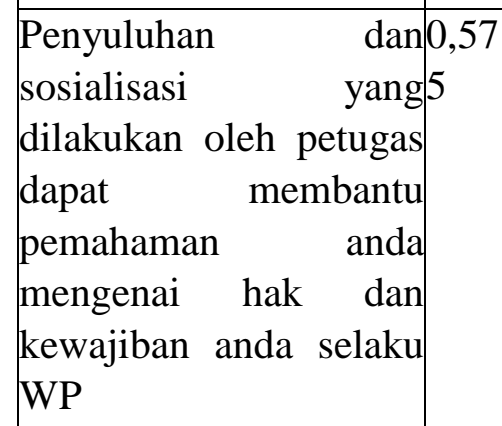 & $\begin{array}{l}0,36 \\
1\end{array}$ & Valid \\
\hline $\begin{array}{llr}\text { Teknologi } & \text { yang0,67 } \\
\text { digunakan KPP } & \text { sudah } 7 \\
\text { cukup modern } & \end{array}$ & $\begin{array}{l}0,36 \\
1\end{array}$ & Valid \\
\hline $\begin{array}{l}\text { Gedung KPP sudah } 0,67 \\
\text { cukup modern (bersih, } 7 \\
\text { rapih dan nyaman) }\end{array}$ & $\begin{array}{l}0,36 \\
1\end{array}$ & Valid \\
\hline \begin{tabular}{lr}
\multicolumn{2}{l}{ Sanksi pajak diperlukan 0,63} \\
agar & tercipta 8 \\
kedisiplinan & Wajib \\
Pajak dalam memenuhi \\
kewajiban perpajakan
\end{tabular} & $\begin{array}{l}0,36 \\
1\end{array}$ & Valid \\
\hline $\begin{array}{l}\text { Pengenaan sanksi harus } 0,50 \\
\text { dilaksanakan dengan } 3 \\
\text { tegas kepada remua } \\
\text { Wajib Pajak yang } \\
\text { melakukan pelanggaran }\end{array}$ & $\begin{array}{l}0,36 \\
1\end{array}$ & Valid \\
\hline $\begin{array}{|lr|}\text { Penetapan } & \text { sanksi } 0,68 \\
\text { perpajakan } & \text { yang } 9 \\
\text { berlaku saat ini } & \text { sudah } \\
\text { tepat } & \end{array}$ & $\begin{array}{l}0,36 \\
1\end{array}$ & Valid \\
\hline
\end{tabular}

Copyright (c) 2021 Sigit Herdianto 
Printed ISSN : $2406-7415$

Electronic ISSN : 2655 - 9919

DOI: http://dx.doi.org/10.35137/jabk.v8i2.551

\begin{tabular}{|l|l|l|l|}
\hline $\begin{array}{l}\text { Sanksi Perpajakan yang } 0,69 \\
\text { berlaku saat ini dapat }\end{array}$ & 0,36 & Valid \\
membuat jera para & 1 & \\
pelanggar peraturan & & & \\
perpajakan & & & \\
\hline $\begin{array}{l}\text { Sanksi pajak dapat } 0,63 \\
\text { meningkatkan } \\
\text { kepatuhan Wajib Pajak }\end{array}$ & 0,36 & Valid \\
\hline $\begin{array}{l}\text { Jika saya selalu } 0,36 \\
\text { terlambat membayar } 5 \\
\text { pajak maka akan } \\
\text { terkena saksi } \\
\text { administrasi }\end{array}$ & 1 & & \\
\hline
\end{tabular}

Jurnal Akuntansi dan Bisnis Krisnadwipayana

Volume 8 No. 2 (Mei - Agustus) 2021

\section{Uji ReliabilitasData}

Tabel 8.Hasil Uji Reliabitas

\begin{tabular}{|c|c|c|c|}
\hline Variabel & $\begin{array}{l}\text { Cronbach } \\
\text { Alpha }\end{array}$ & $\begin{array}{l}\text { koefisien } \\
\text { Cronbach } \\
\text { Alpha }\end{array}$ & $\begin{array}{l}\text { Keterang } \\
\text { an }\end{array}$ \\
\hline \multicolumn{4}{|l|}{ Pengetahuan Perpajakan } \\
\hline $\begin{array}{l}\text { Pajak selaku instrument hukum yang diatur oleh } \\
\text { Undang-Undang adalah suatu kewajiban yang } \\
\text { mengikat bagi setiap Wajib Pajak (WP) }\end{array}$ & 0,926 & 0,6 & Reliabel \\
\hline Pajak mempunyai sifat memaksa & 0,927 & 0,6 & Reliabel \\
\hline $\begin{array}{l}\text { Pajak merupakan penerimaan Negara yang } \\
\text { digunakan untuk } \begin{array}{c}\text { mengarahkan kehidupan } \\
\text { masyarakat menuju kesejahteraan }\end{array}\end{array}$ & 0,925 & 0,6 & Reliabel \\
\hline $\begin{array}{l}\text { Saya mengetahui syarat-syarat untuk mendaftarkan } \\
\text { NPWP, baik syarat subyektif maupun objektif }\end{array}$ & 0,926 & 0,6 & Reliabel \\
\hline $\begin{array}{l}\text { Saya mengetahui tata cara mendaftarkan NPWP } \\
\text { (Nomor Pokok Wajib Pajak) }\end{array}$ & 0,926 & 0,6 & Reliabel \\
\hline Saya mengetahui fungsi NPWP & 0,930 & 0,6 & Reliabel \\
\hline $\begin{array}{l}\text { Saya mengetahui tata cara mengisi E-filling sesuai } \\
\text { dengan peraturan yang berlaku }\end{array}$ & 0,925 & 0,6 & Reliabel \\
\hline $\begin{array}{l}\text { Saya seharusnya menghitung dan menetapkan } \\
\text { sendiri jumlah pajak yang harus disetor } \\
\text { menggunakan aplikasi E-filling }\end{array}$ & 0,923 & 0,6 & Reliabel \\
\hline $\begin{array}{l}\text { Saya wajib mengisi dan menyetorkan E-filling } \\
\text { dengan benar, lengkap dan sesuai pajak yang } \\
\text { dikenakan }\end{array}$ & 0,926 & 0,6 & Reliabel \\
\hline $\begin{array}{l}\text { Saya wajib menyampaikan atau melaporkan e-filling } \\
\text { yang sudah disetorkan ke kantor KPP wilayahnya }\end{array}$ & 0,928 & 0,6 & Reliabel \\
\hline $\begin{array}{l}\text { Saya mengetahui batas waktu penyampaian E-filling } \\
\text { dan pelaporannya }\end{array}$ & 0,927 & 0,6 & Reliabel \\
\hline $\begin{array}{l}\text { Saya mengetahui Sanksi apabila tidak menyetorkan } \\
\text { pajak tepat waktu atau tidak sesuai dengan peraturan } \\
\text { yang berlaku }\end{array}$ & 0,925 & 0,6 & Reliabel \\
\hline \multicolumn{4}{|l|}{ Pelayanan Pajak } \\
\hline Fasilitas yang diterima sudah memadai & 0,927 & 0,6 & Reliabel \\
\hline $\begin{array}{l}\text { Petugas sopan dan memberikan pelayanan dengan } \\
\text { baik }\end{array}$ & 0,926 & 0,6 & Reliabel \\
\hline $\begin{array}{l}\text { Petugas memberikan pelayanan dengan cepat dan } \\
\text { memuaskan }\end{array}$ & 0,925 & 0,6 & Reliabel \\
\hline Petugas tanggap dan sangat membantu & 0,921 & 0,6 & Reliabel \\
\hline $\begin{array}{l}\text { Petugas pajak menguasai dan faham atas pengenaan } \\
\text { pajak yang dilakukan WP }\end{array}$ & 0,926 & 0,6 & Reliabel \\
\hline $\begin{array}{l}\text { Penyuluhan dan sosialisasi yang dilakukan oleh } \\
\text { petugas dapat membantu pemahaman anda mengenai } \\
\text { hak dan kewajiban anda selaku WP }\end{array}$ & 0,927 & 0,6 & Reliabel \\
\hline Teknologi yang digunakan KPP sudah cukup modern & 0,925 & 0,6 & Reliabel \\
\hline $\begin{array}{l}\text { Gedung KPP sudah cukup modern (bersih, rapih dan } \\
\text { nyaman) }\end{array}$ & 0,929 & 0,6 & Reliabel \\
\hline \multicolumn{4}{|l|}{ Sanksi Pajak } \\
\hline $\begin{array}{l}\text { Sanksi pajak diperlukan agar tercipta kedisiplinan } \\
\text { Wajib Pajak dalam memenuhi kewajiban perpajakan }\end{array}$ & 0,925 & 0,6 & Reliabel \\
\hline $\begin{array}{l}\text { Pengenaan sanksi harus dilaksanakan dengan tegas } \\
\text { kepada semua Wajib Pajak yang melakukan } \\
\text { pelanggaran }\end{array}$ & 0,929 & 0,6 & Reliabel \\
\hline $\begin{array}{l}\text { Penetapan sanksi perpajakan yang berlaku saat ini } \\
\text { sudah tepat }\end{array}$ & 0,925 & 0,6 & Reliabel \\
\hline $\begin{array}{l}\text { Sanksi Perpajakan yang berlaku saat ini dapat } \\
\text { membuat jera para pelanggar peraturan perpajakan }\end{array}$ & 0,928 & 0,6 & Reliabel \\
\hline $\begin{array}{l}\text { Sanksi pajak dapat meningkatkan kepatuhan Wajib } \\
\text { Pajak }\end{array}$ & 0,925 & 0,6 & Reliabel \\
\hline $\begin{array}{l}\text { Jika saya selalu terlambat membayar pajak maka } \\
\text { akan terkena saksi administrasi }\end{array}$ & 0,925 & 0,6 & Reliabel \\
\hline
\end{tabular}

257

Copyright (c) 2021 Sigit Herdianto

sehingga

pertanyaan dalam kuesioner pada item-item

pertanyaan kesadaran membayar pajak,

pengetahuan dan pemahaman terhadap

peraturan perpajakan, persepsi atas

efektifitaspelayanan perpajakan dan sanksi

perpajakan terhadap kepatuhan wajib pajak

adalahvalid

This work is licensed under a Creative Commons Attribution-NonCommercial-ShareAlike 4.0 International License 
Printed ISSN : $2406-7415$

Electronic ISSN : 2655 - 9919

DOI: http://dx.doi.org/10.35137/jabk.v8i2.551

Dari tabel 8tersebut dapat diketahui bahwa koefisien Cronbach Alpha > 0,6, sehingga seluruh pertanyaan dalam kuesioner pada item-item pertanyaan variabel pengetahuan dan pemahaman perpajakan, pelayanan pajak dan sanksi pajak terhadap kepatuhan wajib pajak bendahara adalah reliabel.

\section{Uji Normalitas}

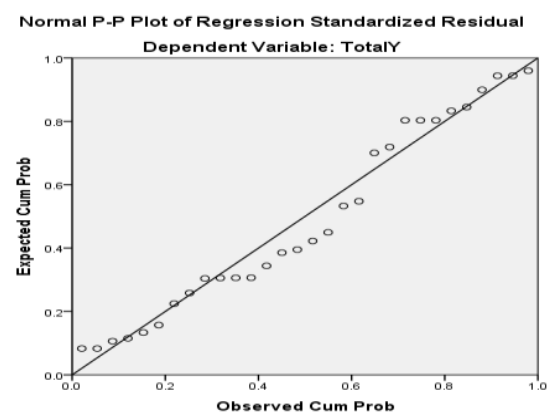

Gambar 2. Plot of Regression

Berdasarkantampilangambar2Normal P-plot,dapatdisimpulkan bahwa pola grafik normal terlihat dari titik-titik yang menyebar di sekitar garisdiagonaldanpenyebarannyamengikutiar ahgarisdiagonal.Halini menunjukkan bahwa model regresi layak dipakai dalam penelitian ini karena memenuhi asumsi normalitas.

Tabel 9.Hasil UjiNormalitas

\section{One-SampleKolmogorov-Smirnov}

Test

\begin{tabular}{|ll|l|}
\hline & & $\begin{array}{l}\text { Unstandardized } \\
\text { Residual }\end{array}$ \\
\hline $\mathrm{N}$ & & 30 \\
Normal & Mean & .0000000 \\
Parameters & Std. & Deviation \\
Most & Absolute & .120 \\
& &
\end{tabular}

\begin{tabular}{|ll|l} 
Extreme & \multicolumn{1}{c}{ Positive } & .120 \\
Differences & Negative & -.116 \\
Test Statistic & & .120 \\
Asymp. Sig. (2-tailed) & $.200^{\mathrm{c}, \mathrm{d}}$ \\
\hline
\end{tabular}

a. Test distribution is Normal.

b. Calculated from data.

c. Lilliefors Significance Correction.

d.This is a lower bound of the true significance.

Berdasarkan output hasil uji normalitas table 9di atas diketahui bahwa seluruh variabel dalam penelitian ini memperoleh nilai signifikansi 0,200 >0.05, sehingga dapat diambil kesimpulan bahwa seluruh data dalam penelitian ini berdistribusi normal.

\section{UjiMultikolinearitas}

Tabel 10. Hasil Uji Multikolinieritas.

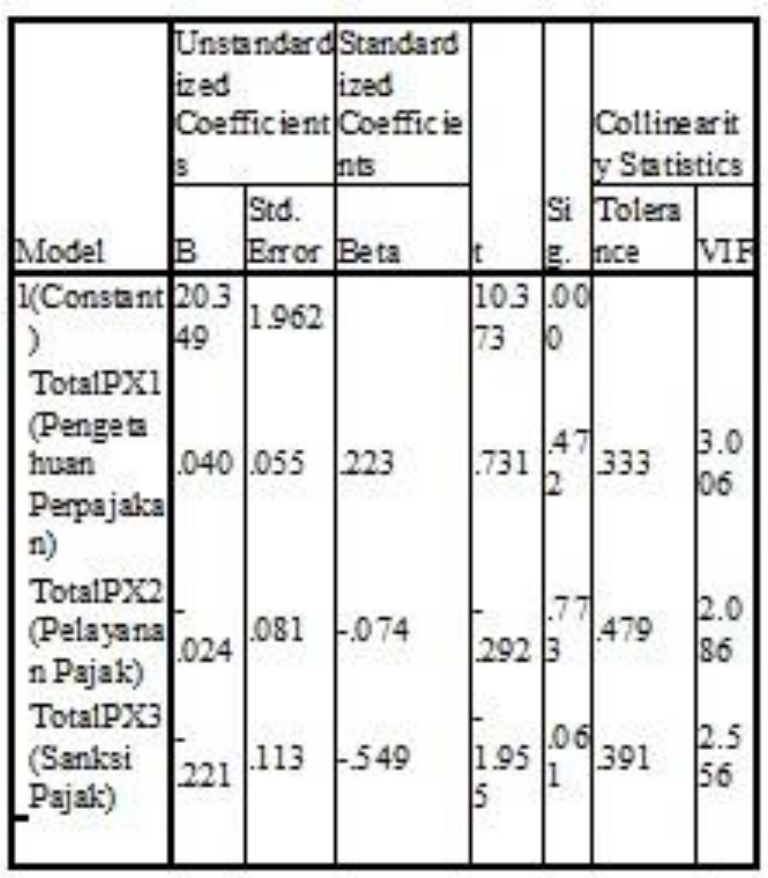

Copyright (c) 2021 Sigit Herdianto 


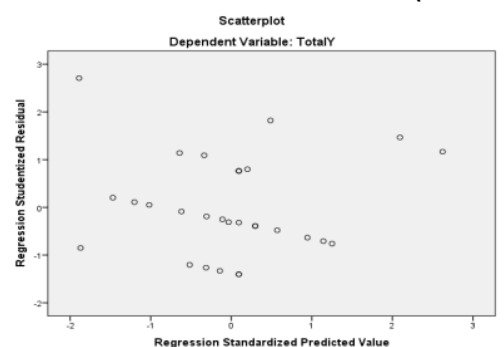

Gambar3. Hasil Plot

\section{Koefisien Determinasi}

\section{UjiHeteroskedastisitas}

Uji heteroskedastisitas ini bertujuan untuk menguji apakah dalam model regresi terjadi ketidaksamaan varian pada residual (error) dari satu pengamatan ke pengamatan yang lain. 1. Jika tidak terlihat pola yang ANOVA $^{\mathrm{a}}$

\begin{tabular}{|c|l|l|l|l|l|}
\hline & $\begin{array}{l}\text { Sum } \\
\text { of } \\
\text { Squar } \\
\text { es }\end{array}$ & $\begin{array}{l}\text { d } \\
\text { f }\end{array}$ & $\begin{array}{l}\text { Mean } \\
\text { Squar }\end{array}$ & F & Sig. \\
\hline $\begin{array}{c}\text { 1 Regressi } \\
\text { on }\end{array}$ & 4.683 & 1 & 4.683 & $\begin{array}{l}6.19 \\
1\end{array}$ & $\begin{array}{l}\text { b } \\
\text { Residual }\end{array}$ \\
$\begin{array}{l}21.18 \\
3\end{array}$ & 2 & .757 & & \\
Total & $\begin{array}{l}25.86 \\
7\end{array}$ & 9 & & & \\
\hline
\end{tabular}

a. Dependent Variable: Kepatuhan WP

b. Predictors: (Constant), Pengetahuan pajak, Pelayanan pajak, Sanksi pajak jelas, serta titik-titik menyebar di atas dan di bawah angka 0 pada sumbu Y, makatidakterjadiheteroskedastisitas.Padapen elitianinitidakterjadiheteroskedasitas, lebih jelasnya dapat dilihat pada gambar3

Tabel11. Koefisien determinasi Model Summary ${ }^{b}$

\begin{tabular}{|c|c|c|c|c|c|}
\hline Mode & $\mathrm{R}$ & \begin{tabular}{|l|}
$\mathrm{R}$ \\
Square
\end{tabular} & $\begin{array}{l}\text { Adjusted } \\
\mathrm{R} \\
\text { Square } \\
\end{array}$ & \begin{tabular}{|l|} 
Std. \\
Error of \\
the \\
Estimate
\end{tabular} & $\begin{array}{l}\text { Durbin- } \\
\text { Watson }\end{array}$ \\
\hline 1 & $.444^{\mathrm{a}}$ & .198 & .105 & .893 & 1.483 \\
\hline
\end{tabular}

a. Predictors: (Constant), Pengetahuan Pajak, Pelayanan Pajak dan Sanksi Pajak

b. Dependent Variable: Kepatuhan Wajib Pajak

Berdasarkan output di atas didapatkan hasil analisis koefisien determinasi sebesar 0,198. Hasil ini diartikan bahwa besarnya variabel independen dalam menjelaskan variabel dependen adalah sebesar 19,8\%. Sedangkan sisanya $80,2 \%$ dipengaruhi faktor lain di luar penelitian

\section{Uji F}

Tabel 12. Uji F

Berdasarkan tabel 12 dapat dilihat bahwa hasil uji $\mathrm{F}$ menunjukkan nilai dari hasil perhitungan, didapatkan Fhitung sebesar 6,191 (signifikansi $F=0,000$ ). Jadi Fhitung $>$ Ftabel $(6,191>2,92)$ atau Sig F < 
Printed ISSN : $2406-7415$

Electronic ISSN : 2655 - 9919

DOI: http://dx.doi.org/10.35137/jabk.v8i2.551

$5 \%(0,019 \%<5 \%)$. Artinya bahwa secara bersama-sama variabel bebasyangterdiridariPengetahuan

Perpajakan(X1),PelayananPajak(X2) dan sanksi pajak (X3) berpengaruh signifikan terhadap variabel kepatuhan wajib pajak(Y)

\section{Uji T}

Tabel 13. Hasil Uji T Pengetahuan Pajak Coefficients $^{\text {a }}$

\begin{tabular}{|c|c|c|c|c|c|c|c|}
\hline \multirow[b]{2}{*}{ Model } & \multicolumn{2}{|c|}{$\begin{array}{l}\text { Unstand } \\
\text { ardized } \\
\text { Coeffici } \\
\text { ents }\end{array}$} & \multirow{2}{*}{\begin{tabular}{|l}
$\begin{array}{l}\text { Stand } \\
\text { ardize } \\
\mathrm{d} \\
\text { Coeff } \\
\text { icient } \\
\mathrm{s}\end{array}$ \\
\\
Beta \\
\end{tabular}} & & & \multicolumn{2}{|c|}{$\begin{array}{l}\text { Collinea } \\
\text { rity } \\
\text { Statistic } \\
\text { s }\end{array}$} \\
\hline & B & $\begin{array}{l}\text { Std } \\
\dot{\text { Err }} \\
\text { or }\end{array}$ & & & $\begin{array}{l}\mathrm{S} \\
\mathrm{i} \\
\mathrm{g} \\
.\end{array}$ & $\begin{array}{l}\text { Tole } \\
\text { ranc } \\
\mathrm{e}\end{array}$ & $\begin{array}{l}\mathrm{V} \\
\mathrm{IF}\end{array}$ \\
\hline $\begin{array}{c}1 \text { (Cons } \\
\tan t)\end{array}$ & $\begin{array}{l}18 \\
.5 \\
74\end{array}$ & $\begin{array}{l}1.6 \\
88\end{array}$ & & $\begin{array}{l}11 \\
.0 \\
04\end{array}$ & $\begin{array}{l}0 \\
0 \\
0\end{array}$ & & \\
\hline $\begin{array}{l}\text { Penge } \\
\text { tahua } \\
\mathrm{n} \\
\text { perpa } \\
\text { jakan }\end{array}$ & $\begin{array}{l}- \\
.0 \\
46\end{array}$ & $\begin{array}{l}.03 \\
3\end{array}$ & -.251 & $\begin{array}{l}- \\
1 . \\
37 \\
4\end{array}$ & $\begin{array}{l}1 \\
8 \\
0\end{array}$ & $\begin{array}{l}1.00 \\
0\end{array}$ & $\begin{array}{l}1 . \\
0 \\
0 \\
0\end{array}$ \\
\hline
\end{tabular}

a. Dependent Variable: Kepatuhan Wajib Pajak

Berdasarkan uji parsial yang telah dilakukan dapat disimpulkan bahwa pengujian variabel pengetahuan perpajakan terhadap variabel ini dilakukan melalui pengujian $\mathrm{p}$-value dari variabel pengetahuan perpajakan. Variabel pertama penelitian ini menyatakan bahwa pengetahuan perpajakan tidak berpengaruh terhadap kepatuhan wajib pajak. Dari hasil analisis data di atas,
Jurnal Akuntansi dan Bisnis Krisnadwipayana Volume 8 No. 2 (Mei - Agustus) 2021 dihasilkan nilai koefisien regresi sebesar 0,046 dan nilai p-value sebesar 0,180. Pada tingkat signifikasi $\alpha=5 \%$, nilai tersebut tidak signifikan karena nilai p-value 0,180>0,05 sehingga dapat disimpulkan bahwa pengetahuan perpajakan tidak berpengaruh terhadap kepatuhan wajib pajak sehingga hipotesis pertama penelitian ini tidak didukung.

Tabel 14. Hasil Uji T Pelayanan Pajak

\section{Coefficients $^{\mathrm{a}}$}

\begin{tabular}{|c|c|c|c|c|c|c|c|}
\hline \multirow[b]{2}{*}{ Model } & \multicolumn{2}{|c|}{$\begin{array}{l}\text { Unstan } \\
\text { dardize } \\
\text { d } \\
\text { Coeffici } \\
\text { ents } \\
\end{array}$} & \multirow{2}{*}{$\begin{array}{l}\text { Stand } \\
\text { ardize } \\
\text { d } \\
\text { Coeffi } \\
\text { cients } \\
\\
\text { Beta } \\
\end{array}$} & \multirow[b]{2}{*}{$\mathrm{t}$} & & \multicolumn{2}{|c|}{$\begin{array}{l}\text { Collinea } \\
\text { rity } \\
\text { Statistics } \\
\end{array}$} \\
\hline & B & $\begin{array}{l}\text { Std } \\
\dot{\text { Err }} \\
\text { or }\end{array}$ & & & $\begin{array}{l}\mathrm{S} \\
\mathrm{i} \\
\mathrm{g} \\
.\end{array}$ & $\begin{array}{l}\text { Tole } \\
\text { ranc } \\
\mathrm{e}\end{array}$ & $\begin{array}{l}\text { V } \\
\text { IF }\end{array}$ \\
\hline $\begin{array}{l}1 \text { (Con } \\
\text { stant } \\
)^{2}\end{array}$ & $\begin{array}{l}19 . \\
04 \\
0\end{array}$ & $\begin{array}{l}1.8 \\
90\end{array}$ & & $\begin{array}{l}10 . \\
07 \\
3\end{array}$ & $\begin{array}{l}0 \\
0 \\
0\end{array}$ & & \\
\hline $\begin{array}{l}\text { Pela } \\
\text { yana } \\
\mathrm{n} \\
\text { Paja } \\
\mathrm{k}\end{array}$ & $\begin{array}{l}- \\
.08 \\
6\end{array}$ & $\begin{array}{l}.05 \\
8\end{array}$ & -.268 & $\begin{array}{l}- \\
1.4 \\
73\end{array}$ & $\begin{array}{l}1 \\
5 \\
2\end{array}$ & $\begin{array}{l}1.00 \\
0\end{array}$ & $\begin{array}{l}1 . \\
00 \\
0\end{array}$ \\
\hline
\end{tabular}

a. Dependent Variable: Kepatuhan Wajib Pajak

Berdasarkan uji parsial yang telah dilakukan dapat disimpulkan bahwa pengujian variabel pelayanan pajak terhadap variabel ini dilakukan melalui pengujian pvalue dari variabel pelayanan pajak. Variabelkedua penelitian ini menyatakan bahwa pelayanan pajak tidak berpengaruh terhadap kepatuhan wajib pajak. Dari hasil analisis data di atas, dihasilkan nilai 
Printed ISSN : $2406-7415$

Electronic ISSN : 2655 - 9919

DOI: http://dx.doi.org/10.35137/jabk.v8i2.551

Jurnal Akuntansi dan Bisnis Krisnadwipayana Volume 8 No. 2 (Mei - Agustus) 2021

koefisien regresi sebesar $-0,086$ dan nilai $\mathrm{p}$ value sebesar 0,152. Pada tingkat signifikasi $\alpha=5 \%$, nilai tersebut tidak signifikan karena nilai p-value $0,152>0,05$ sehingga dapat disimpulkan bahwa pelayanan pajak tidak berpengaruh terhadap kepatuhan wajib pajak sehingga variabelkedua penelitian ini tidak didukung

Tabel 15. Hasil Uji T Sanksi Pajak

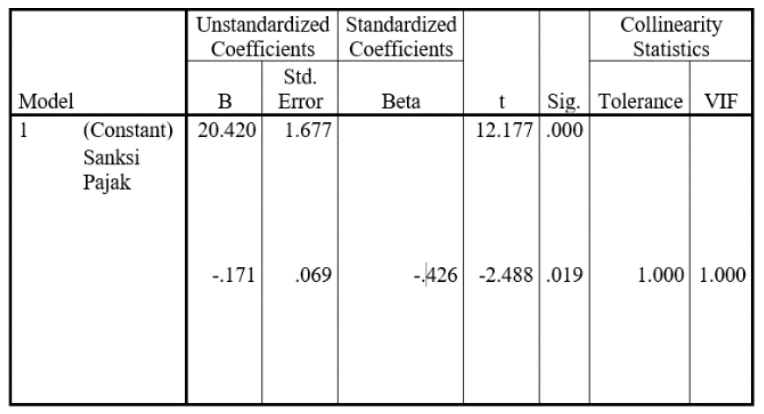

Berdasarkan uji parsial yang telah dilakukan dapat disimpulkan bahwa pengujian variabel sanksi pajak terhadap variabel ini dilakukan melalui pengujian $\mathrm{p}$ value dari variabel sanksi pajak. Variabelketiga penelitian ini menyatakan bahwa sanksi pajak berpengaruh terhadap kepatuhan wajib pajak. Dari hasil analisis data di atas, dihasilkan nilai koefisien regresi sebesar -0,171 dan nilai p-value sebesar 0,019. Pada tingkat signifikasi $\alpha=5 \%$, nilai tersebut signifikan karena nilai p-value $\quad 0,019<0,05 \quad$ sehingga dapat disimpulkan bahwa sanksi pajak berpengaruh terhadap kepatuhan wajib pajak sehingga variable ketiga penelitian ini didukung

Tabel 15. Hasil Uji T Ketiga Variabel

\section{Coefficients $^{\mathrm{a}}$}

\begin{tabular}{|c|c|c|c|c|c|c|c|c|}
\hline \multirow{2}{*}{\multicolumn{2}{|c|}{ Model }} & \multicolumn{2}{|c|}{$\begin{array}{c}\text { Unstandardized } \\
\text { Coefficients }\end{array}$} & \multirow{2}{*}{\begin{tabular}{|c|}
$\begin{array}{c}\text { Standardized } \\
\text { Coefficients }\end{array}$ \\
Beta \\
\end{tabular}} & \multirow[b]{2}{*}{$\mathrm{t}$} & \multirow[b]{2}{*}{ Sig. } & \multicolumn{2}{|c|}{$\begin{array}{c}\text { Collinearity } \\
\text { Statistics }\end{array}$} \\
\hline & & $\mathrm{B}$ & $\begin{array}{l}\text { Std. } \\
\text { Error }\end{array}$ & & & & \begin{tabular}{|c|}
$\begin{array}{c}\text { Tolera } \\
\text { nce }\end{array}$ \\
\end{tabular} & VIF \\
\hline \multirow[t]{4}{*}{1} & (Constant) & 20.349 & 1.962 & & 10.373 & .000 & & \\
\hline & TotalPX1 & .040 & .055 & .223 & .731 & .472 & .333 & 3.006 \\
\hline & TotalPX2 & -.024 & .081 & -.074 & -.292 & .773 & .479 & 2.086 \\
\hline & TotalPX3 & -.221 & .113 & -.549 & -1.955 & .061 & .391 & 2.556 \\
\hline
\end{tabular}

a. Dependent Variable: total Y (Kepatuhan Wajib Pajak)

\section{Pembahasan}

\section{Pengaruh Pengetahuan Perpajakan terhadap Kepatuhan WajibPajak}

Hipotesis pertama untuk menguji kebenaran atas pengaruh secara parsial pengetahuan perpajakan wajib pajak terhadap kepatuhan wajib pajak. Hipotesis pertama dari hasil penelitian ini membuktikan bahwa pengetahuan perpajakan wajib pajak tidaksignifikan atau tidak berpengaruh terhadap kepatuhan wajib pajak. Hal ini ditunjukkan dengan hasil uji t pada variabel kesadaran wajib pajak yaitu sebesar 0,731 dengan tingkat signifikansi sebesar 0,472>0,05 sehingga $\mathrm{H} 1$ ditolak artinya pengetahuan perpajakan wajib pajak tidak berpengaruh terhadap kepatuhan wajib pajak secara statistik signifikan pada taraf signifikansi 5\%. Artinya baik atau tidaknya pengetahuan perpajakan para wajib pajak bendahara pemerintah, tidak mempunyai pengaruh terhadap kepatuhan wajib pajak dalam memenuhi kewajiban perpajakannya. Kualitas pengetahuan perpajakan dari wajib pajak belum dapat memenuhi atau melebihi harapan para wajib pajak. Baik atau tidaknya pengetahuan wajib pajak bendahara pemerintah tidak membantu kenaikan atau penurunan pertamabahan nilai pajak yang diterima pemerintah untuk memajukan pengembanagan pemerintah. Hasil penelitian ini sejalan dengan penelitian Pranadata (2014). 
Printed ISSN : $2406-7415$

Electronic ISSN : 2655 - 9919

DOI: http://dx.doi.org/10.35137/jabk.v8i2.551

Pengaruh Pelayanan Pajak terhadap Kepatuhan Wajib Pajak

Hasil Hipotesis kedua dari hasil penelitian ini membuktikan bahwa kualitas pelayanan pajak tidak berpengaruh terhadap kepatuhan wajib pajak Hal ini ditunjukkan dengan hasil uji $\mathrm{t}$ pada variabel kualitas pelayanan pajak yaitu sebesar $-0,292$ dengan tingkat signifikansi sebesar 0,773> 0,05 sehingga $\mathrm{H} 2$ ditolak, yang berarti bahwa kualitas pelayanan pajak tidak berpengaruh terhadap kepatuhan wajib pajak secara statistik signifikan. Artinya baik atau tidaknya pelayanan pajak yang diberikan kepada wajib pajak, tidak mempunyai pengaruh terhadap kepatuhan wajib pajak dalam memenuhi kewajiban perpajakannya. Kualitas pelayanan pajak dari aparat pajak belum dapat memenuhi atau melebihi harapan para wajib pajak. Adanya oknum-oknum yang menyalahgunakan dana pajak juga membuat kepercayaan wajib pajak kepada aparat pajak menjadi turun. Selain itu kurangnya cepat tanggap dari petugas pajak dalam membantu menyelesaikan persoalan yang dihadapi wajib pajak juga dapat menjadi faktor bahwa pelayanan yang diberikan belum sesuai harapan para wajib pajak. Hasil penelitian ini sejalan dengan penelitian Pranadata (2014) dan Dewi Dewi (2015).

\section{Pengaruh SanksiPajak terhadap Kepatuhan Wajib Pajak}

Berdasarkan hipotesis ketiga membuktikan bahwa sanksi perpajakan tidak berpengaruh terhadap kepatuhan wajib pajak. Hal ini ditunjukkan dengan hasil uji t pada variabel sanksi perpajakan yaitu
Jurnal Akuntansi dan Bisnis Krisnadwipayana Volume 8 No. 2 (Mei - Agustus) 2021 sebesar -1,955 dengan tingkat signifikansi sebesar 0,061>0,05 sehingga H3 ditolak yang berarti bahwa sanksi perpajakan tidak berpengaruh terhadap kepatuhan wajib pajak secara statistik signifikan. Artinya, tegas atau tidaknya sanksi pajak yang diberikan kepada wajib pajak, hal itu tidak mempengaruhi wajib pajak dalam mematuhi kewajiban perpajakannya. Hal ini dapat terjadi karena pengenaan sanksi pajak belum cukup tegas kepada semua wajib pajak yang melakukan pelanggaran. Selain itu, sikap acuh dari wajib pajak yang belum jera atas sanksi yang diterimanya dapat menjadi faktor yang mempengaruhi bahwa sanksi tidak berpengaruh terhadap kepatuhan wajib pajak. Dengan demikian, tegas atau tidaknya saknsi yang diberikan tidak mempengaruhi tingkat kepatuhan wajib pajak. Hasil penelitian ini sejalan dengan penelitian Hananto (2015).

Pajak bersifat wajib, dapat dipaksakan dan tidak memiliki timbal balik secara langsung. Dalam hal ini kepatuhan wajib pajak merupakan sikap yang penting bagi setiap wajib pajak. Semakin meningkatnya kepatuhanwajib pajak maka semakin bertambah pendapatan dari sektor pajak. Oleh karena itu dalam hal ini pemerintah melakukan berbagai cara untuk meningkatkan

kepatuhanwajibpajak,danberbagaipihaksepe rtiwajibpajakharuspatuhdan sadar melaksanakan kewajiban pajaknya sebagai wajib pajak. Penelitian- penelitian yang dilakukan para peneliti mengenai analisis faktor-faktor yang mempengaruhi wajib pajak juga turut membantu pemerintah dalam mengetahui penyebab atas ketidakpatuhan wajib pajak. Dalam hal ini penulis melakukan penelitian mengenai 
Printed ISSN : $2406-7415$

Electronic ISSN : 2655 - 9919

DOI: http://dx.doi.org/10.35137/jabk.v8i2.551 faktor-faktor yang mempengaruhi kepatuhan wajib pajak dan menggunakan tiga variabel antara lain pengetahuan perpajakan, pelayanan pajak dan sanksipajak.

Berdasarkan penelitian yang dilakukan oleh penulis yang dilakukan denganpengujiansecarastatistikyangtelahdii nterpretasikan,diketahuibahwa secara simultan variabel pengetahuan perpajakan wajib pajak, pelayanan fiskus dan sanksi pajak secara bersama-sama tidak berpengaruh signifikan terhadap kepatuhan wajib pajak bendahara satker di lingkungan Badan Narkotika Nasional.Namun berbeda dengananalisissecaraparsial,menunjukkanuji variable yaitu pengetahuan perpajakan dengan pelayanan pajak tidak berpengaruh signifikan terhadap kepatuhan wajib pajak namun pada uji variable yaitu sanksi pajak terlihat bahwa adanya sanksi pajak dapat berpengaruh signifikan terhadap kepatuhan wajib pajak bendahara di Lingkungan Badan Narkotika Nasional.

\section{KESIMPULAN DAN SARAN}

\section{Kesimpulan}

1. Pengetahuan berdasarkan dikatakan perpajakan berpengaruh perpajakan (X1) parameter statistik bahwa pengetahuan wajib pajak tidak kepatuhan wajib pajak (Y) dalam memenuhi kewajibannya. Sehingga pada uji hipotesis ini tidak membuktikan bahwa semakin tinggi pengetahuan perpajakan maka tingkat kepatuhan perpajakan wajib pajak meningkat pada wajib pajak bendahara di Lingkungan Badan Narkotika Nasional semakin baik.
Jurnal Akuntansi dan Bisnis Krisnadwipayana Volume 8 No. 2 (Mei - Agustus) 2021

2. Pelayanan perpajakan (X2) berdasarkan parameter statistik dikatakan bahwa pelayanan perpajakan wajib pajak tidak berpengaruh terhadap kepatuhan wajib pajak (Y) dalam memenuhi kewajibannya. Sehingga pada uji hipotesis ini tidak membuktikan bahwa semakin tinggi pelayanan perpajakan maka tingkat kepatuhan perpajakan wajib pajak meningkat pada wajib pajak bendahara di Lingkungan Badan Narkotika Nasional semakin baik.

3. Sanksi pajak (X3) berdasarkan parameter statistik dikatakan bahwa sanksi wajib pajak tidak berpengaruh terhadap kepatuhan wajib pajak (Y) dalam memenuhi kewajibannya. Sehingga pada uji hipotesis ini tidak membuktikan bahwa semakin tegas dan berat sanksi pajak maka tingkat kepatuhan perpajakan wajib pajak meningkat pada wajib pajak bendahara di Lingkungan Badan Narkotika Nasional semakin baik.

4. Berbeda dengananalisissecaraparsial,menunjukka npada uji variable yaitu pengetahuan perpajakan (X1) dengan pelayanan pajak (X2) tidak berpengaruh signifikan terhadap kepatuhan wajib pajak (Y), namun pada uji variable yaitu sanksi pajak (X3) terlihat bahwa adanya pengaruh signifikan terhadap kepatuhan wajib pajak (Y) bendahara di Lingkungan Badan Narkotika Nasional.Sehingga terjadi ketidakpastian yang signifikan dalam penelitian ini.

\section{Saran}

1. Bagi akademisi sebagai bahan masukan untuk meningkatkan kesadaran mengenai pentingnya membayar pajak, harus mengetahui bahwa pajak yang 
Printed ISSN : $2406-7415$

Electronic ISSN : 2655 - 9919

DOI: http://dx.doi.org/10.35137/jabk.v8i2.551

dibayarkan langsung masuk ke kas negara dan dipergunakan negara untuk kepentingan umum, pembangunan, dan biaya penyelenggaraan negara.

2. Bagi Praktisi Hasil penelitian ini dapat menjadi informasi tambahan dan refensi dalam usaha peningkatan kepatuhan perpajakan terutama dalam kaitannya dengan sistem administrasi perpajakan, kualitas pelayanan pajak, penegakan hukum perpajakan, pemeriksaan pajak, tarif pajak, kesadaran wajib pajak, dan perilaku wajib pajak khususnya diwilayah penelitian.

3. Bagi peneliti selanjutnya, perlu ditambahkan penelitian yang mendalam tentang kepatuhan wajib pajak dengan menambah variabel bebas selain yang ada dalam penelitian ini seperti keadaan ekonomi negara, system administrasi perpajakan di Indonesia, dan lain-lain yang bisa mempengaruhi kepatuhan wajibpajak.Perluditambahkanjumlahresp ondenatauobjekpenelitian,sehinggaakan menghasilkan data yang lebih baik dan pengukuran yang lebihtepat.

\section{DAFTAR PUSTAKA}

Dewi, Fransisca Novieta Afsari. 2013. Pengaruh Pengetahuan Pajak, Kualitas Pelayanan dan Sanksi Perpajakan Terhadap Kepatuhan Wajib Pajak Orang Pribadi (Studi Empiris di Kantor Pelayanan Pajak (KPP) Pratama Mataram Barat). Skripsi. Yogyakara: Fakultas Ekonomi Jurusan Akuntansi Universitas Sanata Dharma Dirjen Pajak: strategi dan capaian
Jurnal Akuntansi dan Bisnis Krisnadwipayana Volume 8 No. 2 (Mei - Agustus) 2021 penerimaan pajak tahun 2019. http://www.online-

pajak.com/dirjen-pajak-strategidan-capaian-penerimaan-pajaktahun-2019.

Dirjen Pajak. 2013. Susunan Dalam Satu Naskah Undang-Undang Perpajakan. Jakarta Selatan. Direktorat Penyuluhan, Pelayanan, dan Hubungan Masyarakat.

Dirjen Pajak. 2013. Undang-Undang PPN dan Peraturan Pelaksanaannya. Jakarta Selatan. Direktorat Penyuluhan, Pelayanan, dan Hubungan Masyarakat.

Dirjen Pajak. 2013. Undang-Undang PPh dan Peraturan Pelaksanaannya. Jakarta Selatan. Direktorat Penyuluhan, Pelayanan, dan Hubungan Masyarakat.

Dirjen Pajak. 2016. Bendahara Mahir Pajak. Edisi Revisi. Jakarta. Direktorat Peraturan Perpajakan II.

Fatimah, Euis. 2011. Buku Panduan Hak dan Kewajiban Wajib Pajak. Jakarta. Dirjen Pajak.

Fuadi, A. O., \& Yenny, M., (2013). Pengaruh kualitas pelayanan petugas pajak, sanski, perpajakandan biaya kepatuhan pajak terhadap kepatuhan wajib pajak UMKM. Jurnal Tax \& Accounting Review Volume 1 No.1.

Hananto, Samudra Dhony. 2015. Pengaruh SPPT, Sanksi, Pendapatan Wajib Pajak Terhadap Kepatuhan Wajib Pajak Bumi dan Bangunan. Skripsi, Universitas Dian Nuswantoro Semarang

Harjowiryono, M. (2019). Analisis faktorfaktor yang memengaruhi kepatuhan bendahara 
Printed ISSN : $2406-7415$

Electronic ISSN : 2655 - 9919

DOI: http://dx.doi.org/10.35137/jabk.v8i2.551 pemerintah dalam penyetoran pajak.Indonesian Treasury Review: Jurnal Perbendaharaan, Keuangan Negara Dan Kebijakan Publik, 4(3), 195-217.

Kamil, Nurlis Islamiah. 2015. The Effectof Taxpayer Awarness, Knowledge, Tax Penalties and Tax Authorities Services on The Tax Compliance: (Survey on The Individual Taxpayer at Jabodetabek \& Bandung. Research Journal of Finance and AccountingVol.6 No.2. 2015.

Maya Tantio Dharma; Stefanus Ariyanto. 2014.Analisis Faktor - Faktor yang Mempengaruhi Tingkat Kepatuhan Wajib Pajak Orang Pribadi di Lingkungan Kantor Pelayanan Pajak Pratama, Tigaraksa Tangerang. Skripsi. Universitas BINUS.

Mardiasmo. 2016. Perpajakan. Yogyakarta. Penerbit Andi.

Peraturan Menteri Keuangan Republik Indonesia Nomor 192/PMK.03/2007 pasal 1. http://www.ortax.org/ortax/?mod=a turan \&page $=$ show \&id $=13038$.

Diunduh 27 November 2020.

Pohan, Chairil Anwar. 2017. Manajaemen Perpajakan. Jakarta. PT. Gramedia Pustaka Utama.

Pranadata, I Gede Putu . 2014. Pengaruh Pemahaman Wajib Pajak, Kualitas Pelayanan Perpajakan, dan Pelaksanaan Sanksi Pajak, Terhadap Kepatuhan Perpajakan Wajib Pajak Orang Pribadi Pada KPP Pratama Batu. Skripsi. Fakultas Ekonomi dan Bisnis Universitas Brawijaya Malang.
Jurnal Akuntansi dan Bisnis Krisnadwipayana Volume 8 No. 2 (Mei - Agustus) 2021

Resmi, Siti. 2019. Perpajakan Teori dan Kasus. Edisi 11. Jakarta. Salemba Empat.

Sari, R. I. \& Nuswantara, D. A. (2017). The Influence of Tax Amnesty Benefit Perception to Taxpayer Compliance. Jurnal Dinamika Akuntansi, 9(2), 176-183.

Suandy, Erly. 2016. Perencanaan Pajak. Edisi 6. Jakarta. Salemba Empat.

Suprianto, Edy. 2011. Akuntansi Perpajakan. Edisi Pertama. Yogyakarta. Graha Ilmu.

Waluyo. 2016. Akuntansi Pajak. Edisi 6. Jakarta.Salemba Empat.

Winerung, Oktaviane Lidya. 2013. Sosialisasi Perpajakan, Pelayanan Fiskus dan Sanksi Perpajakan Terhadap Kepatuhan WPOP di KPP Manado dan KPP Bitung. Jurnal EMBA, Vol.1. 